\title{
FAKTOR-FAKTOR YANG MEMPENGARUHI PENGGUNAAN KONTRASEPSI DAN HAK REPRODUKSI PEREMPUAN PADA KELUARGA AKSEPTOR KB DI KELURAHAN MACCORAWALIE KAB. PINRANG
}

\author{
St. Hardiyanti ${ }^{*}$ Idham Irwansyah ${ }^{2}$ \\ ${ }^{1}$ Mahasiswa/Sosiologi \\ Universitas Negeri Makassar \\ Email: sitihrdynti@gmail.com \\ ${ }^{2}$ Dosen/ Sosiologi \\ Universitas Negeri Makassar \\ Email: idhamunm@gmail.com
}

\begin{abstract}
ABSTRAK
Penelitian ini menunjukan bahwa faktor pendorong akseptor menggunakan KB yaitu pertama, faktor eksternal, merupakan faktor pendorong yang muncul diluar dari kondisi satu keluarga dimana peran pemerintah serta lembaga-lembaga terkait memainkan peran aktif dalam berbagai sosialisasi penyuluhan dan yang kedua faktor internal, faktor yang didasarkan pada situasi atau kondisi yang ada didalam satu keluarga yaitu karena Ingin menunda kehamilan, dikarenakan oleh faktor ekonomi dimana akseptor dalam keluarga memiliki tingkat ekonomi yang rendah dan faktor pekerjaan dimana akseptor memiliki kesibukan dalam pekerjaannya, selain daripada itu, faktor pendorong akseptor melakukan KB untuk menjaga jarak kelahirannya dikarenakan keluarga lebih cenderung memilih mengatur jarak kelahiran anak serta mengikuti program KB untuk menekan laju pertumbuhan penduduk. Dari hasil penelitian juga dapat disimpulkan bahwa kedudukan perempuan dalam hak reproduksi dalam memilih metode kontrasepsi dilakukan atas dasar keputusan bersama antara suami dan istri, namun ada juga keputusan diambil oleh satu pihak saja.
\end{abstract}

Kata kunci: Faktor pendorong, hak reproduksi, KB

\begin{abstract}
ABSTRAK
The results of this study indicate that the driving factors for acceptors to use family planning are, first, external factors, which are driving factors that arise outside of the condition of a family where the role of the government and related institutions plyas an active role in various outreach socializations and the second is internal factors, factors based on in a situation or condition that exists in one family, namely because you want to delay pregnancy, due to economic factors where the acceptors in the family have a low economic
\end{abstract}


Jurnal Predestination: jurnal of Society and Culture.

Vol .1 No.2, Maret 2021

level and work factors where the acceptors are busy in their, apart from that, the driving factor for the acceptors to do family planning is to keep their distance births because families prefer to regulate the birth spacing of children and participate in family planning programs to reduce population growth rates. From the research result it can also be concluded that the position of women in reproductive rights in choosing contraceptive methods is based on a joint decision between husband and wife, but there is also a decision made by one party only.

Keywords: driving factor, reproductive rights, family planning

\section{PENDAHULUAN}

Pelaksanaan keluarga berencana sejatinya sudah dimulai sejak tahun 1957, akan tetapi presiden pada saat itu, yakni Ir soekarno yang belum terlepas dari euforia kemerdekaan merasa yakin dan optimis dengan menyatakan bahwa indonesia mempunyai kekayaan alam cukup untuk menghidupi lebih dari 250 juta penduduk. Dimasa awal tahap perkembangannya, maka metode kontrasepsi yang dipakai untuk pelaksanaan KB ini menggunakan semacam penghalang yang dipasang di alat vital perempuan. Percobaan KB pertama kalinya dipelopori oleh dr. kun martiono, berupa potongan kain kasa yang diujungnya dijahitkan dengan benang yang kemudian dicelupkan kedalam minyak kelapa (Nindita Farah 2011)

Dalam pelaksaan program keluarga berencana, perempuan harus diposisikan sebagai subjek, dengan demikian hak-hak reproduksinya termasuk hak dalam pengambilan keputusan harus dihargai. Dalam hal otoritas pengambilan keputusan masih ditangan suami, salah satu indikasi dari lemahnya posisi perempuan dimasyarakat adalah dari tingkat perlindungan terhadap perempuan dalam proses reproduksi di Indonesia belum cukup. Perkembangan gagasan bahwa jumlah penduduk perlu dikontrol agar tidak menghambat gerak pembangunan menjadi alasan negara dengan penduduk padat seperti Indonesia untuk membatasi pertumbuhan penduduk. Program dan pelayanan KB yang dirancangkan pemerintah lebih mengejar target daripada untuk memperhatikan kualitas pelayanannya. (Nindita Farah 2011). Adapun faktor yang menyebabkan keluarga menggunakan KB yaitu karena inginnya menunda kehamilan dikarenakan dimana faktor ekonomi yang tidak mencukupi dan faktor pekerjaan yang mengharuskan menunda kehamilannya dan ingin mengatur jarak kelahiran anaknya

\section{METODE}

Pada pembahasan awal penelitian ini diuraikan temuan data penelitian yang diperoleh dari hasil observasi dan wawancara terhadap informan penelitian. Proses observasi dalam hal ini peneliti melakukan pengamatan langsung terhadap aktivitas akseptor pengguna $\mathrm{KB}$ di Kelurahan Maccorawalie. Data observasi tersebut dikonfirmasikan kepada semua informan yang telah dipilih kemudian mereka di wawancarai dengan merujuk pada pedoman wawancara yang telah disusun sebelumnya sesuai kategori dan fokus permasalahan penelitian

Penelitian ini dilakukan di kelurahan maccorawalie, Kabupaten Pinrang. Mengapa peneliti memilih lokasi ini dikarenakan menurut peneliti, kelurahan maccorawalie merupakan salah satu kelurahan yang banyak menggunakan KB. 
Jurnal Predestination: jurnal of Society and Culture.

Vol .1 No.2, Maret 2021

Penelitian ini menggunakan penelitian jenis kualitatif dengan penekanan Observasional Analitik melalui pendekatan Cross Sectional. Yaitu dengan observasi langsung ke objek sasaran riset ( Suharsini Arikunto 2006)

\section{HASIL DAN PEMBAHASAN}

Penelitian ini menggunakan teori tindakan sosial. Menurut Max Weber, metode yang bisa di pergunakan untuk memahami arti-arti subjektif tindakan sosial seseorang adalah dengan verstehen. Istilah ini tidak hanya sekedar merupakan intropeksi yang cuma bisa digunakan untuk memahami arti subjektif tindakan diri sendiri, bukan tindakan subjektif orang lain. Mungkin aspek pemikiran weber yang paling terkenal mencerminkan tradisi idealis adalah tekanannya pada versteben (pemahaman subjektif) sebagai metode untuk memperoleh pemahaman yang valid mengenai arti-arti subyektif tindakan sosial.

Sebaliknya Weber berpendirian bahwa sosiologi haruslah merupakan suatu ilmu empirik; sosilogi harus menganalisa perilaku aktual manusia individual menurut orientasi subyektif mereka sendiri. (Doyle 1986) Kalau tindakan sosial itu harus dimengerti dalam hubungan dengan arti subjektif yang terkandung didalamnya, perlu di kembangkan suatu metode untuk mengetahui arti subyektif ini secara obyektif dan analisis.

Dalam keadaan tidak ada metode seperti itu, namun bagi Weber, konsep rasionalitas merupakan kunci bagi suatu analisa obyektif mengenai arti-arti subyektif dan juga merupakan dasar perbandingan mengenai jenis-jenis tindakan sosial yang berbeda. (Doyle 1986)

Faktor pendorong/penyebab akseptor menggunakan KB

Faktor pendorong dapat diartikan sebagai motivasi atau dorongan yang membuat seseorang melakukan suatu tindakan guna mencapai tujuan. Motivasi erat kaitannya dengan kebutuhan, banyak orang bekerja karna berkaitan dengan kebutuhan.

Adapun faktor faktor penyebab/pendorong akseptor menggunakan kb yaitu karena pertama faktor eksternal. Salah satu faktor pilihan keluarga melaksanakan program KB ialah adanya program penyuluhan dan sosialisasi dari dinas-dinas terkait beserta dukungan yang besar dari pemerintah setempat dan kedua faktor internal yang dimana ingin menunda kehamilannya dikarenakan faktor ekonomi yang menjadi kendala ekonominya tidak mencukupi sehingga akseptor dikelurahan maccorawalie menunda kehamilannya, faktor pekerjaan yang dimana beberapa keluarga sibuk dengan pekerjaannya sehingga tidak mempunyai waktu luang untuk mengurusi anak dan ingin menjaga jarak kelahiran dan ingin menjaga jarak kelahiran anaknya.

Kedudukan perempuan yang memiliki hak reproduksinya

Dan dari hasil penelitian ada beberapa bentuk hak reproduksi Pertama, Hak pasangan atau individu dalam memutuskan ikut program KB. Kedua, Hak pasangan atau individu dalam membuat keputusan terkait jumlah, jedah dan waktu mempunyai anak. Ketiga, Hak pasangan atau individu untuk mendapatkan informasi dan pelayanan kesehatan reproduksi. Juga dapat disimpulkan bahwa kedudukan perempuan dalam hak reproduksi dalam memilih metode 
Jurnal Predestination: jurnal of Society and Culture.

Vol .1 No.2, Maret 2021

kontrasepsi dilakukan atas dasar keputusan bersama antara suami dan istri, namun ada juga keputusan diambil oleh satu pihak saja.

Dalam pembahasan ini, peneliti berusaha menguraikan atau menganalisis hasil penelitian serta mempertaukan dengan beberapa teori yang dianggap relevan. Secara khusus, terdapat dua poin penting menjadi pokok pembahasan. Pertama, Faktor pendorong atau penyebab akseptor menggunakan $\mathrm{KB}$, Kedua, kedudukan perempuan yang memiliki hak reproduksi sebagai pelaksana program $\mathrm{KB}$

\section{Faktor pendorong atau penyebab akseptor menggunakan $\mathrm{KB}$}

Keluarga merupakan satuan atau unit terkecil dalam masyarakat. Fridmen mendefenisikan bahwa, keluarga merupakan dua orang atau lebih yang hidup bersama dengan keterkaitan aturan atau emosional. Dan di dalamnya setiap anggota mempunyai peran masing-masing yang merupakan bagian dari anggota keluarga tersebut

Dalam kontek ini penting untuk melihat keterkaitan antara peran struktur dalam hal ini Negara atau pemerintah serta hubungannya dalam pembentukan prespektif atau nilai baru dalam masyarakat. Weber menjelaskan, antara struktur sosial dan pranta sosial tidaklah terpisah secara tegas. Struktur sosial dan pranata sosial keduanya membantu untuk membentuk tindakan manusia yang penuh arti dan penuh makna (George Ritzer 2011). Hubungan antara kedua hal tersebut menawarkan satu metedologi dalam memahami satu tindakan yang penuh makna.

Tindakan yang hadir dalam pilihan untuk mengikuti program KB dapat diklasifikasikan sebagai bentuk tindakan instrumental yang dimana didalamnya terdapat tujuan atau pertimbangan yang sudah dipikirkan sebelumnya. Atau dengan kata lain tindakan tersebut tidak muncul secara spontanitas. Weber menjelaskan, Rasionalitas instrumental ini meliputi pertimbangan dan pilihan yang sadar yang berhubungan dengan tujun tindakan itu dan alat yang dipergunakan untuk mencapainya. Individu dilihat sebagai memiliki macam-macam tujuan yang mungkin diinginkannya, dan atas dasar suatu kriterium menentukan suatu pilihan diantara suatu tujuan-tujuan yang saling bersaingan ini. Individu itu lalu menilai alat yang mungkin dapat digunakan untuk mencapai tujuan yang dipilih tadi (Paul Doyle Jhonson 1986).

\section{Kedudukan perempuan yang memiliki hak reproduksi sebagai pelaksana program KB}

Dalam penelitian ini, peneliti menemukan ada beberapa bentuk hak reproduksi Pertama, Hak pasangan atau individu dalam memutuskan ikut program KB. Kedua, Hak pasangan atau individu dalam membuat keputusan terkait jumlah, jedah dan waktu mempunyai anak. Ketiga, Hak pasangan atau individu untuk mendapatkan informasi dan pelayanan kesehatan reproduksi.

Dalam hal perencanaan mengikuti program KB umumnya keputusan itu berangkat dari hasil kesepakatan bersama antara suami dan istri. Pola ini hampir sama didapati baik keluarga yang usia pernikahannya masih muda maupun sudah cukup lama 
Jurnal Predestination: jurnal of Society and Culture.

Vol .1 No.2, Maret 2021

Umumnya pertimbangan ini juga mengacuh pada kondisi ekonomi keluarga, pola komunikasi dalam keluarga merupakan hal yang dinamis yang sesuai dengan kebutuhankebutuhan keluarga, Pengambilan keputusan merupakan perwujudan proses yang terjadi dalam keluarga dan merupakan hasil interaksi antara peran anggota keluarga untuk saling mempengaruhi. Dengan mengetahui pola pengambilan keputusan rumah tangga, dapat diketahui pula ada tidaknya dominasi dalam suatu rumah tangga. (Soerjono Soekanto 2012)

Hal serupa juga terlihat dalam keputusan terkait jumlah, jedah dan waktu mempunyai anak. Pertimbangan dalam mengatur waktu kehamilan juga berangkat dari kesepakatan bersama antara suami dan istri. Adapun yang menjadi pertimbangan ialah, faktor ekonomi keluarga, faktor pekerjaan (dalam hal ini perempuan juga bekerja), dan keinginan untuk fokus pengasuah anak. Scanzoni (dalam Lestari 1990: 93) menjelaskan bahwa, pengambilan keputusan yang diambil sebaiknya merupakan hasil kesepakatan bersama, Menurut Weber (1978), dikatakan bahwa pengembilan keputusan dalam keluarga selalu dikaitkan dengan struktur kuasa dalam keluarga. Kuasa didefinisikan sebagai kemungkinan bahwa di dalam satu hubungan sosial seorang pelaku mampu merealisasikan kehendaknnya, sekalipun ada tantangan (Paul Doyle Jhonson 1986)

Dalam penelitian ini, terlihat pula bagaimana peran perempuan jauh lebih aktif. Hal ini terlihat dalam hal mendapatkan informasi dan pelayanan kesehatan reproduksi. Berangkat dari kepedulian akan kesehatan reproduksinya, mereka secara berinisiatif atau turut serta dalam berbagai kegiatan penyuluhan kesehatan reproduksi yang dilakukan pemerintah. Hal ini didasarkan pertimbangan lingkup permasalahan kesehatan juga menjadi masalah kaum perempuan. Oleh karena itu, perempuan perlu mengetahui seluruh seluk beluk yang dibutuhkan perempuan yang berkaitan dengan kesehatannya.

Pada akhirnya analisis dalam penelitian ini dapat memmbatu mengindentifikasi situasi aktual kedudukan perempuan dalam pengambilan keputusan terkait dengan hak dan kesehatan reproduksi. Tingkat akses dan kontrol perempuan sudah mengalami kemajuan, meskipun pada beberapa kondisi tindakan laki-laki yang superior dan bersifat patriarkis masih terjadi. Namun, di antara mereka sudah tampak adanya ketergantungan antara satu dengan lainnya dan saling mengisi peran antara suami dan istri.

\section{KESIMPULAN}

Dari hasil penelitian ini menunjukan bahwa Ada beberapa faktor akseptor memilih untuk melakukan KB, Pertama, faktor eksternal. merupakan faktor pendorong yang muncul diluar dari kondisi satu keluarga. Dalam hal ini peneliti melihat peran pemerintah serta lembaga-lambaga terkait memainkan peran aktif dalam berbagai sosialisasi serta penyuluhan terkait dengan program KB. Kedua faktor internal. Faktor yang dasarkan pada situasi atau kondisi yang ada dalam satu keluarga. Adapun kondisi atau pertimbangan-pertimbagan tersebut seputar kondisi ekonomi keluarga, kondisi pekerjaan, dan keinginan untuk mengatur jarak kelahiran. Dua faktor tersebut menjadi penyebab akseptor memilih untuk melakukan KB. Dari hasil penelitian ada beberapa bentuk hak reproduksi Pertama, Hak pasangan atau individu dalam memutuskan ikut program KB. Kedua, Hak pasangan atau individu dalam membuat keputusan terkait jumlah, jedah dan waktu mempunyai anak. Ketiga, Hak pasangan atau individu untuk mendapatkan informasi dan pelayanan kesehatan reproduksi. Juga dapat 
Jurnal Predestination: jurnal of Society and Culture.

Vol .1 No.2, Maret 2021

disimpulkan bahwa kedudukan perempuan dalam hak reproduksi dalam memilih metode kontrasepsi dilakukan atas dasar keputusan bersama antara suami dan istri, namun ada juga keputusan diambil oleh satu pihak saja.

\section{DAFTAR PUSTAKA}

Arikunto Suharsini. (2006). Prosedur Penelitian Praktek. Rineka Cipta: Jakarta

George Ritzer. (2011). Sosiologi Ilmu Pengetahuan Berparadigma Ganda. Rajawali Pres: Jakarta

Lestari, I. (1990). "Pengambilan Keputusan dalam Keluarga”, Jakarta: Lembaga Penerbitan Fakultas Ekonomi Universitas Indonesia

Paul Doyle Johnson. (1986). Teori Sosiologi Klasik Dan Modern. PT Gramedia Pustaka Utama: Jakarta

Soerjono Soekanto. (2012). Sosiologi Suatu Pengantar. Rajawali Pers: Jakarta

Nindita Farah. (2011). Dominasi maskulin dalam program keluarga berencana. 